\title{
Türkiye’de Kamu Kesimi Kaynak Tahsisinde Etkinliğin Sağlanması Amacıyla Mali Alan Oluşturma Çabaları ${ }^{1}$
}

\author{
Mustafa Alpin GÜLŞEN*, Uğur ÇİÇEK ${ }^{* *}$ \\ öz
}

Günümüzde kamu kesiminin artan sorumlulukları, kamusal finansmana ilişkin önerilerin ortaya konulmasını zorunlu kılmaktadır. Bu önerilerin başında gelen mali alan, bir ülkenin makroekonomik planlarına uygun olarak mali sürdürülebilirliklerine zarar vermeden finansal kaynak yaratma kapasitesini ifade etmektedir. Çalışmada kamu kaynak tahsisinde etkinliğin sağlanması amacıyla mali alan oluşturma çabasının Türkiye'de kamu kesimi açısından önemi ve reel politika oluşturma sürecindeki uyumu vurgulanmaktadır. Çalıșmanın amacı mali alan kavramının açıklanması, uluslararası kuruluşların mali alan oluşturma konusundaki önerilerinin belirtilmesidir. Çalışmada, Türkiye'de mali alanın oluşturulması sonrasında elde edilen kaynakların ne şekilde kullanıldığı konusunda genel bir değerlendirme yapılmaktadır. Buna göre özellikle faiz harcamalarının azaltılıp mali alan oluşturulduğu görülmektedir.

Anahtar Kelimeler: Mali Alan, Kamu Harcamaları, Kaynak Tahsisi

JEL Sınıflandırması E62, H50, H30.

\section{Efforts Towards Creating Fiscal Space to Ensure Effective Allocation of Public Resources in Turkey}

\begin{abstract}
Increasing responsibilities of public sector make it imperative to offer suggestions for the financing problem. The fiscal space at the beginning of these proposals refers to the capacity to generate financial resources in accordance with the macroeconomic plans of an entity, without harming its fiscal sustainability. The fiscal space emerges as a concept that aims to increase public income. This study is important as it examines the significance of creating a fiscal space for efficient allocation of public resources in Turkey, aiming to explain the concept of fiscal space, describing suggestions of international institutions and showing the developments in Turkish economy. We offer a general assessment on the utilization of the financial resources after the creation of the fiscal space in Turkey. Efforts to establish the fiscal space have been positive. Accordingly, it is seen that interest expenditures are reduced and financial area is created.
\end{abstract}

Keywords: Fiscal Space, Public Expenditure, Resource Allocation

JEL Classification: E62, H50, H30.

Geliş Tarihi/Received: 21.01.2018 Kabul Tarihi/Accepted: 01.04.2018

\footnotetext{
${ }^{1} \mathrm{Bu}$ makale, 28 Eylül - 1 Ekim 2017 tarihlerinde Antalya'da gerçekleştirilen II. Uluslararasi Stratejik Araştirmalar Kongresinde sözlü bildiri olarak sunulmuştur.

* Öğr. Gör., Akdeniz Üniversitesi, Kumluca Meslek Yüksekokulu, Finans Bankacılık ve Sigortacılık Bölümü, m.alpingulsen@gmail.com, ORCID: 0000-0002-2860-4469.

** Dr. Öğr. Üyesi, Mehmet Akif Ersoy Üniversitesi, Zeliha Tolunay Uygulamalı Teknoloji ve İşletmecilik Yüksekokulu, Muhasebe ve Finansal Yönetim Bölümü, ugurcicek@mehmetakif.edu.tr, ORCID:0000-0003-13572561.
} 


\section{GİRIŞ}

Günümüzde kamu kesiminin rolünün ulusal ölçekte artması beraberinde finansman sorununu gündeme getirmekte; uluslararası finansal piyasaların genişlemesi de ekonomi üzerinde önemli bir etken olmaktadır. Kamu kesiminin ekonomik büyüme, fiyat istikrarı ve piyasa dinamiklerinin üretmek istemediği mal ve hizmetleri üretme zorunluluğu gibi ekonomik sorumluluğunun yanında yoksulluğu azaltmaya, gelir dağılımında adaleti sağlamaya ve işsizliği önlemeye yönelik sosyal politika harcamalarını da üstlenmesi neticesinde yapılacak harcamaların finansmanın nasıl karşılanacağı hususu yüksek bir öneme sahip olmuştur. Ekonomik krizlerin neden olduğu mali sorumlulukların çoğunlukla kamu kesimi bütçesinden karşılanması ve bununla birlikte gelişmiş ekonomilerin borç yükümlülüklerinde meydana gelen büyük artışlar, finansman sorununu ayrıca önemli hale getiren faktörlerden olmuştur. Söz konusu soruna yönelik yapılan önerilerden biri olan mali alan kavramı bu kapsamda çalışmanın konusunu oluşturmaktadır.

Çalışmada öncelikle mali alan kavramının teorik çerçevesine değinilmektedir. İkinci olarak mali alanı oluşturma yöntemleri, üçüncü olarak ise maliye politikası uygulamalarında mali alanın konumu analiz edilmektedir. Çalışmada son olarak Türkiye'de mali alan ve mali alanın kullanımına ilişkin değerlendirmelere yer verilmektedir.

\section{MALI ALAN KAVRAMI}

Mali alan kavramı kamu kesiminin ekonomik kalkınma ve sosyal politika amaçlarına ulaşabilmesi için finansal kaynak yaratabilme kabiliyetini ifade etmektedir. Mali alan, Gayrisafi Yurtiçi Hasıla (GSYİH) içindeki kamu gelirlerinin payını ölçerek tahmin edilebilecek niceliksel ve bütçesel bir boyuta sahip olarak ifade edilmektedir. Bununla birlikte mali alan kavramının sadece ilave bir kamu geliri yaratabilme kabiliyeti ile sınırlı olduğu düşünülmemelidir. Kamu kesimi, ekonomik büyüme yoluyla da mali alan oluşturabileceği gibi mali sürdürülebilirliği ve mali disiplini negatif etkilememek koşuluyla borçlanmayla da mali alan oluşturabilme imkânına sahiptir. Ek olarak mali alan kavramı, yapısal dönüşümü destekleyecek önlemleri içeren kamu harcamamalarını arttırma potansiyelini de ifade etmektedir (UNCTAD, 2014:161). Literatürde her ne kadar farklı tanımlar olsa da söz konusu kavramı ilk olarak 2005 yılında kullanan (Aşan, 2014:35) Peter Heller mali alanı, bir hükümetin ekonominin mali durumunun sürdürülebilirliğine herhangi bir zarar vermeden, hedeflenen bir amaç için kaynak sağlamasına imkân tanıyan "bütçe odası" şeklinde tanımlamaktadır (Heller, 2005:3).

Dolayısıyla mali alan kavramıyla ilgili yapılan tanımlarda mali sürdürülebilirlik, orta ve uzun vadeli makroekonomik hedefler, kaynak havuzu bulma ve mali disiplinin oluşturulması da ön plana çıkmaktadır (Ünsal ve Durucan, 2013:29).

Mali sürdürülebilirlik, kamu kesimi borç stokunun ekonomideki payının sürekli bir şekilde artmaması durumu olarak tanımlanabilir. Bir diğer ifadeyle kamu kesiminin makroekonomik hedeflerini herhangi bir borç yükümlügüne girmeden uygulayabilme kapasitesi; borçlanma ile finanse edildiği durumlarda ise borç ödeme gücünün ${ }^{2}$ geleceğe aktarılması olarak tanımlanmaktadır. Bu açıdan mali alan ile mali sürdürülebilirlik arasında birtakım ilişkileri bulunmaktadır. $\mathrm{Bu}$ ilişkilerden ilki, mali alana duyulan ihtiyacın karşılanması için kısa veya uzun vadede yapılacak yüksek kamu harcamasının bugünkü ve gelecekteki gelirlerden sağlanması gerekmesinden kaynaklanmaktadır. Bu harcamaların borç ile finanse edilmesi kamu

\footnotetext{
${ }^{2}$ Borç ödeme gücü veya mali yeterlilik (fiscal solvency) kısaca kamu kesiminin borç yükümlülüğünü karşılayabilme yeterliliğini ifade etmektedir (Mendoza ve Oviedo, 2009:135)
} 
kesiminin bugünkü ve gelecekteki gelir üretme kapasitesinin düşük olduğunu göstermektedir. Söz konusu ilişkilerin ikincisi ise; cari harcama programlarının orta ve uzun vadeli etkilerine yönelik mali alan oluşturulmasının, mali sürdürülebilirlik üzerinde önemli bir etkiye sahip olmasıyla ilgilidir. Söz konusu cari harcamaların, gelecekte yeni bir harcama yapılmasını zorunlu kılıp kılmaması, dolayısıyla gelecekte ilave bir mali alana ihtiyaç duyulup duyulmayacağı hususunun mali sürdürülebilirlik ile yakından ilişkili olduğunu göstermektir (Heller, 2005:4).

Diğer taraftan mali alan ve mali sürdürebilirlik ile ilgili söylenenlerin doğal bir koşulu olarak mali disiplin konusu ortaya çıkmaktadır. Bütçe dengesinin kısa ve orta vadede tutarlılığın sağlanması olarak ifade edilen mali disiplinin sağlanması için özellikle konjonktürel mali risklerin artış gösterdiği dönemlerde bütçe açıklarının finansmanını sağlamada bir mali alanın hazır bulunması gerekmektedir. Bu açıdan mali disiplin ile mali sürdürülebilirlik kavramlarının birbirlerini tamamlayıcı nitelikte olduğu ifade edilebilir.

Mali alan ile ilgili orta ve uzun vadeli makroekonomik hedeflere ulaşma isteği ekonomilerin gelişmişlik seviyelerine göre farklılıklar göstermektedir. Dolayısıyla ulaşılmak istenen hedefler, söz konusu ekonomilerin hangi mali kaynakları kullanabilecekleri sorununu gündeme getirmektedir. Bir diğer ifadeyle ulaşılmak istenen sosyal ve ekonomik hedefler, bu politikaların finansman sorununu da beraberinde getirmektedir. Kamu kesiminin hangi kaynaklardan finansman sağlayacağı ise ülkelerin ekonomik seviyelerine göre değişiklik göstermektedir.

Kavramsal çerçeveye ek olarak mali alan kavramı (kamu harcamalarına finansman sağlaması bakımından) Birleşmiş Milletlerin öncülügünde Binyıl Kalkınma Hedefleriyle birlikte gündeme gelmiştir (Ünsal ve Durucan, 2013:29). 2000 yılında 147 devlet ve hükümet başkanının da dahil olduğu 189 ulusun temsilcileri biraraya gelerek Binyıl Kalkınma Hedefleri'nin kabul edilmiş; yoksulluk, eğitim ve kalkınma gibi temel sorunlara 21 'inci yüzyıl içinde son verilmesi amaçlanmıştır (DPT, 2010:12). Binyıl Kalkınma programında belirtilen 8 hedef aşağıdaki gibidir:

1. Aşırı yoksulluk ve açlığın ortadan kaldırılması

2. Evrensel ilköğretimin gerçekleştirilmesi

3. Kadın-erkek eşitliğinin sağlanması ve kadınların konumunun güçlendirilmesi

4. Açlık çeken nüfusun yarı yarıya azaltılması

5. Anne sağlığının iyileştirilmesi

6. HIV/AIDS, sitma ve diğer hastalıklarla mücadele edilmesi

7. Çevresel sürdürülebilirliğin sağlanması

8. Kalkınma için küresel bir ortaklık geliştirilmesi

UNDP'ye göre (2016:13) yukarıda sayılan hedeflere ulaşmada ekonomilerin gelişmişlik seviyelerine göre harcama ve gelir politikalarının belirlenmesi gerekmektedir. Finansman kaynaklarını tahsis etme seçenekleri ise mali alan yaratmaktan iklim finansmanını kullanmaya, yoksullara faydası olmayan sübvansiyonları kesmekten kaynakları daha etkin kullanmaya kadar uzanan geniş bir yelpazede yer almaktadır.

\section{MALİ ALAN OLUSTTURMA YÖNTEMLERİ}

Kamu kesiminin finansman bulabilme kabiliyeti ile ilgili olarak mali alan oluşturabilmenin çeşitli yöntemleri bulunmaktadır. Söz konusu hedeflere ulaşabilmek için 
ülkelerin ekonomik gelişmişlik seviyesine göre belirlenmesi gereken birtakım yöntemlere ihtiyaç duyulmaktadır. Dolayısıyla ülkelerin hangi amaçla mali alan oluşturacağ oluşturabilme kabiliyeti farklılık arz etmektedir. Bu bağlamda ülkeler, teknolojik yeniliklerin gerektirdiği kurumsal ve altyapısal revizyonlar ile yoksulluğun azaltılmasına veya ortadan kaldırılmasına yönelik politikalar aracılılığıyla mevcut toplumsal ve ekonomik yapıyı çağdaş ekonomiler seviyesine getirebilmek gibi nedenlerle mali alana ihtiyaç duymaktadır. Mali alan oluşturabilme yöntemleri şu şekilde özetlenmektedir:

Kamu kesimi harcamalarının etkinliğinin arttırılması: Toplumsal ve küresel gelişmeler neticesinde kamu kesimi harcamalarının artış göstermesi, kamu kesimi kaynaklarının en az maliyet-en fazla fayda prensibiyle kullanılması gerekliliğini ön plana çıkarmaktadır. Az gelişmiş ve gelişmekte olan ülkelerin birçoğunda aşırı maliyet, verimsiz proje yönetimi ve altyapı yatırımları ile kamu kesiminin kaynaklarının etkin kullanılmadığı ifade edilmektedir.

Vergi önlemlerinin alınması: Vergi yükünün nispeten düşük olduğu ülkeler, gelirlerini artırmak için birtakım tedbirler alarak mali alan oluşturma firsatına sahiptirler. Bunun yanında, vergi oranlarını yükseltmek yerine vergi tabanının genişletilmesi ve vergi idaresinin denetim gücünün arttırılması da tercih edilmektedir (Linde, 2011:2).

Bununla birlikte vergi oranlarının arttırılması mevcut vergi yükünü de arttırarak iç talebi daraltıcı bir etkide bulunabilir. Bu etki sonucunda merkezi yönetimin vergi gelirlerinde artış olmasının yanında vergi kaçağı sorunu da ortaya çıkabilir. Literatürde Laffer eğrisi olarak adlandırılan bu etkiye göre vergi haddi ile vergi geliri arasında önce aynı sonra ters yönlü bir iliş̧i meydana gelecek, vergi haddi arttıkça vergi geliri önce artacak daha sonra ise azalma eğilimde olacaktır (Ünsal, 2009:571). Bu açıdan vergi yükünün daha adil bir sistemle paylaştırılması veya vergi idarelerinin daha etkin bir sistemle çalıştırılması nispeten faydalı olacaktır.

Özel sektör girişimlerinin varllğg: Ekonomilerde özel sektörün yaygınlığı kamu kesiminin mali kaynak ihtiyacını ve sunacağ 1 hizmet türlerini azaltmaktadır. Ek olarak altyap1 yatırımlarının kamu kesimi yerine özel sektör tarafından üstlenilmesi de bu yatırımların bütçeden değil sermaye piyasaları tarafından finanse edilmesi sonucunu doğurarak ilave bir mali alan oluşturulmasına katkıda bulunacaktır (Linde, 2011:3). Dolayısıyla piyasa dinamikleri tarafindan üretilecek mal ve hizmetleri kamu kesiminin üstlenmesi, bütçe üzerinde negatif etkide bulunacaktır. Bu etki sonucunda mali alan daralarak hedeflenen politikalar için finansman zorluğu olacaktır.

Uluslararası yardımlar: Özellikle düşük gelirli ülkelerin mali alan oluşturma konusunda sınırlı hareket alanı bulunmaktadır. Dolayısıyla söz konusu ülkelerin ulusal kaynaklardan gelir elde etme imkânına kavuşana kadar mali alan oluşturmak için orta vadede dış kaynaklardan hibe yardımları alması gerekmektedir (Linde, 2011:3). Mali alanı oluşturacak bu yöntem daha çok az gelişmiş ve merkezi yönetimin olmadığı veya zayıf olduğu ülkelerde görülmektedir.

Kamu iktisadi teşekkülü: Verimsiz ve zarar eden kamu iktisadi teşekkülleri, daha üretken amaçlar için kullanılabilecek bütçe kaynaklarını olumsuz etkilemektedir. $\mathrm{Bu}$ durum kamu kesimi borç yükünü arttırmakta; mali alan oluşturma kabiliyetini sınırlandırmaktadır (Linde, 2011:3).

Borçlanma: Bir diğer mali alan kaynağını ise kamu kesiminin borçlanma kapasitesi oluşturmaktadır. Borçlanma kapasitesi de mevcut borcun miktarına, şarta bağlı yükümlülüklere ve teminatların derecesine göre sınırlanmaktadır. Dolayısıyla ekonomilerin büyüme beklentisi ne kadar güçlü olursa borçlanma kaynağı bulabilme ve borç ödeme gücü de o kadar artacak ve böylece mali alan oluşturmada önemli bir avantaj sağlamış olacaktır. Ek olarak mali yönetimin disiplinli olmasıyla birlikte düşük borç stoku ve makroekonomik istikrara sahip ekonomiler, uluslararası piyasalardan düşük faizle borçlanarak düşük faizden kaynaklanan ilave bir mali alan 
imkânına sahip olmuş olacaktır (Linde, 2011: 3). Bu açıdan mali alanın gelecekte genişleyeceği beklentisi ekonomilerin mali riskinin düşük olduğunu gösterecek ve böylece borçlanma maliyetini nispeten düşürmüş olacaktır. Borçlanma maliyetinin düşmesi faiz ödemelerinin bütçede oluşturacağı yükü azaltarak mali alanı genişleten önemli bir faktör olacaktır.

Yukarıda bahsedilen mali alan oluşturmada kullanılabilecek yöntemlerin seçiminde ülkelerin kendine özgü koşulları önem arz etmektedir. Bir diğer ifadeyle mali alan oluşturmak, bir ülkedeki başlangıç koşullarına, kamu kurumlarının güçlü ve zayıf yanlarına ve performanslarını iyileştirmek için yaptıkları veya yapacakları reformlara bağlıdır. Her ülkede farklı olmakla birlikte ülkelerin mali alan oluşturma seçenekleri "mali alan elması" ile sembolize edilmektedir. Bu tipolojide ülkeler borçlanmaya, uluslararası yardıma, gelirlerini yükseltme çabasına ve harcamalarının etkinliğini yükseltmesine göre değerlendirilmektedir (Dünya Bankası (WB), 2006:27). Mali alanın genişlemesine imkân sağlayan söz konusu dört kaynağın uygulanmasında ise makroekonomik istikrar ve mali sürdürülebilirlik konularına önem verilmesi gerekmektedir (Roy vd., 2007:20). Mali alan elması Şekil 1'de kaynaklar itibarıla gösterilmiştir:

Şekil 1'de gösterilen mali alan elmasının şekli, kaynakların her birinin mali alana göreceli katkısını göstermektedir. Söz konusu katkılar şöyle ifade edilebilir (Heller, 2006:75-77):

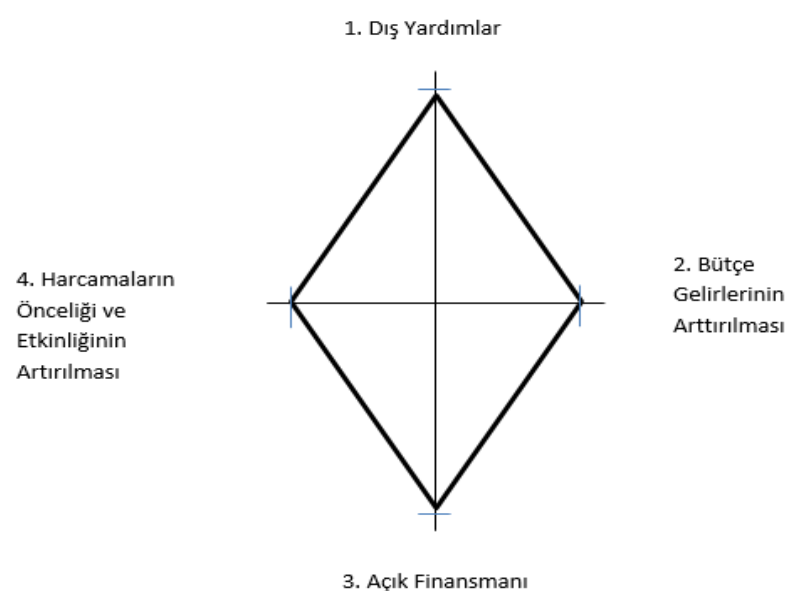

Şekil 1: Mali Alan Elmas1

Kaynak: (Roy,2007:6).

GSYİH içinde Kamu Kesimi Gelirlerinin Artırılması: Bu finansman kaynağı, vergi yükü düşük olan ekonomiler için etkin bir seçenektir. Gelir düzeyi düşük olan ülkelerde vergilerin payını GSYIH'nin en az \%15'i düzeyine yükseltmek asgari bir hedef olarak gösterilmektedir.

Kamu kesimi harcamalarının önceliklendirilmesi: Mali alanını genişletmek isteyen hükümetlerin verimsiz harcamaları azaltarak bu harcamalarını öncelik sırasına göre yeniden düzenlemesi gerekmektedir. Bu seçenek özellikle kamu kesimi harcamasının GSYİH içindeki payının yüksek olduğu ülkeler için önem arz etmektedir.

Dış yardımlar: Dış yardımlar, borçlanma seçeneğinin aksine açık bir şekilde mali alan sağlamaktadır. Bunun nedeni, borçlanmanın gelecekteki borç ödeme yükümlülüğünü artırmasının yanında mali alanı da daraltmış olmasıdır. Ancak yardımların da sürekli olup olmaması ve miktarın öngörülebilir olması önem taşımaktadır. Ayrıca, yardımlara olan 
bağımlılığın artması durumunda ülkelerin mali alan yaratma kabiliyetinin azalma ihtimali de yüksek olacaktır.

Borçlanma: İlave mali alan yaratmada bir diğer seçenek de iç ve dış borçlanmadır. Ancak iç veya dış borçlanma tek başına borç miktarıyla değerlendirilmemeli; borcun faizi ve vadesi, gelecekte yaratacağı veya daraltacağı mali alanı, geri ödemede kullanılacak gelirlerin finansmanı da göz önünde bulundurulmalıdır.

Para Basma: Mali alan yaratmada bir diğer seçenek olan para basma, yeterli likiditenin olmadığı durumlarda enflasyonu tetiklemeyecek şekilde tercih edilebilir. Ancak bu seçenek oldukça sınırlı olup genellikle enflasyonist etkilere neden olmaktadır.

\section{MALIYYE POLITÍKASI UYGULAMALARINDA MALİ ALANIN KONUMU}

Mali alan kavramı doğası gereği maliye politikası hedeflerinin uygulanması hususunda önemli bir firsat vermektedir. Ekonomik istikrarının sağlanmasında, gelir dağılımının iyileştirilmesinde veya ekonomik büyümeyi sağlamada kamu kesiminin uygulayacağ 1 politikaların finansmanı, mali alan vasıtasıyla oluşturulabilmektedir. Kamu kesiminin vergiler, kamu harcamaları ve borçlanma gibi maliye politikası araçlarını kullanarak mali alan yaratabilme kapasitesi, kamu kesimi kaynaklarının makroekonomik hedeflere aktarılmasına katkıda bulunmaktadır.

Bununla birlikte kamu kesimi harcamaları hem mali yeterlilik hem de makroekonomik istikrar açısından sınırlandırılmıştır. Ülkelerin kısa vadeli makroekonomik istikrardan ödün vermeksizin kamu harcamalarını artırabildiğinde ortaya çıkan "Makroekonomik Alan (Macroeconomic Space)" hem mali hem de bunları üstlenen ülkeler tarafından karşı karşıya kalınan makroekonomik kısıtlamalar dahilinde yapılmaktadır. Bu açıdan kamu kesimi, mali yeterlilik (ödeme gücü) ve mali sürdürülebilirliği sağlama konusunda önemli sorumluluklar üstlendiği için ilave bir harcama yaptı̆̆ında mali ve makroekonomik alana ihtiyaç duymaktadır (Perotti, 2007:18). Dolayısıyla makroekonomik alan kavramı makroekonomik istikrarın korunmasıyla birlikte kamu harcamalarını artırma becerisi olarak ifade edilmekte (WB, 2009:199); mali alanı belirlemede önemli bir rol üstlenmektedir.

$\mathrm{Bu}$ kapsamda etkili bir maliye politikası hem makroekonomik istikrarı hem de mali yeterliliği dikkate alacak şekilde tasarlanmalıdır. Söz konusu ilişki Tablo 1'de gösterilmektedir.

Tablo 1: Makroekonomik ve Mali Alanın Alternatif Senaryoları

\begin{tabular}{|c|c|c|}
\hline $\begin{array}{l}\text { İstikrar } \\
\text { Mali Alan }\end{array}$ & $\begin{array}{l}\text { Ödeme Gücü Güçlü } \\
\text { (Mali Alanın Varlığı) }\end{array}$ & $\begin{array}{l}\text { Ödeme Gücü Zayıf } \\
\text { (Mali Alanın Yokluğu) }\end{array}$ \\
\hline Makroekonomik istikrar sürdürülebilir & A & B \\
\hline Makroekonomik istikrar riskli durumda & $\mathrm{C}$ & $\mathrm{D}$ \\
\hline
\end{tabular}

Kaynak: (WB, 2006:29).

Tablo 1, makroekonomik istikrar ile ödeme gücünü içermektedir. Maliye politikasındaki değişiklikler makroekonomik etkilere sahip olduğu için ödeme gücü kamu harcamaları üzerinde tek başına kısıtlayıcı bir faktör değildir. Kamu kesiminin harcamalarındaki artış hem ödeme gücüyle (mali yeterlilikle) uyumlu olduğunda hem de makroekonomik istikrarı olumsuz etkilemediği durumda, kamu kesimi harcamalarının verimliliğini artırmaktadır. $\mathrm{Bu}$ durum Tablonun A bölgesinde gösterilmekte, genellikle konjonktür karşıtı maliye politikası (countercyclical fiscal policy) uygulandığında ortaya çıkmaktadır. Buna karşılık, Tablonun C 
bölgesinde, harcamaların genişlemesine yönelik maliye politikaları, ekonominin tam istihdamda olabilmesi ve borç ödeme gücünü arttırsa bile mali genişleme istikrarı bozucu bir etkiye yol açabileceği için tercih edilmeyecektir. Kamu harcamalarının genişlemesinin borç ödeme gücünü güçlendirdiği fakat makroekonomik istikrarı zayıflattığı bu gibi durumlarda, mali genişlemenin makroekonomik istikrarla tutarlı olmasını sağlamak için diğer politikaları (örneğin daraltıcı para politikaları) uygulamak gerekli olabilir (WB, 2006: 29). Diğer taraftan Tablonun B bölgesinde bulunan mali alanının olmadığı ülkeler kamu harcamalarının etkinliğini artırarak makroekonomik istikrarı sürdürülebilir kılacak maliye politikaları izleme firsatı bulabilir. Ek olarak mevcut kamu harcamalarının sabit halde kalması veya üretken alanlara kaydırılması da benzer katkıyı sağlamış olacaktır. Son olarak mali alanın olmadığı durumu ifade eden D bölgesinde, daraltıcı maliye politikasıyla makroekonomik istikrar riskli durumdan çıkma fırsatına sahip olacaktır. Bu durumda borç stokunun azalmasıyla orta ve uzun vadede mali alan genişleyecektir.

$\mathrm{Bu}$ kapsamda ülkelerin maliye politikalarını oluşturma ve uygulama konusunda borçlanma düzeyi ve kamu açıklarının durumu, mali anlamda hareket alanlarını gösteren önemli bir gösterge olmaktadır. Mali yeterlilik ve mali sürdürülebilirlik hususlarında makroekonomik istikrarı olumsuz etkilemeden, karşı dönemsel maliye politikası uygulayabilmenin mümkün olması durumu olarak ifade edilen mali alan, daralma dönemlerinde daha kolay kaynak bulma ve harcama imkânı vermektedir. Ülkelerin kamu kesimi borç stokları, karşı dönemsel maliye politikası uygulamalarına imkân veren kaynakların kısıtlanmasına yol açan borç servisi hususunu beraberinde getirerek mali alanı daraltmakta, bununla birlikte mali teşviklerin alternatif maliyetini gösteren borç faiz oranlarının seviyesi de söz konusu mali alanı daraltan ilave bir sorun olarak karşımıza çıkmaktadır. Mali açıdan diğer ülkelere bağımlılı̆̆ 1 yüksek olan ekonomilerde mali teşvikler yerine ağırlığın kur düzenlemelerine kaydırılması mali çarpanı etkisiz bırakmakta (veya etkisini azaltmakta), maliye politikası yerine para politikası regülasyonlarının yapılması neticesinde ise bir maliye politikası aracı olan mali alan oluşturma seçeneği gücünü kaybetmektedir.

Günümüzde küreselleşmeye yönelik uygulanan politikalara paralel olarak uluslararası iş birliğinin olmaması, vergi tabanının aşınmasının yanı sıra mali alanı da daraltıcı etkide bulunabilmektedir. $\mathrm{Bu}$ açıdan ulusal vergi politikaları, uluslararası birtakım etkilere neden olabilir. Örneğin, vergi teşvikine yönelik alınan olumsuz kararlar neticesinde, doğrudan yabanc1 yatırımlar nispeten daha olumlu vergi teşviki politikası uygulayan ülke/ülkelere yönelebilir ve böylece büyüme beklentileri düşerek vergi tabanında bozulma meydana gelebilir. $\mathrm{Bu}$ durum ise düşük gelirli ülkelerde artan kamu harcamalarının kapsamını önemli ölçüde sınırlandırarak gelir arttırma ihtiyacı ile yatırımları teşvik etme arasında kararsızlığa sebep olabilir. Dolayısıyla vergi rekabetinin arttığı günümüzde söz konusu olumsuz durumlardan kaçınmak adına uluslararası iş birliğine de ihtiyaç duyulabilmektedir. Bununla birlikte birtakım büyüme odaklı maliye politikaları reformlarının uygulanması da mali alan gerektirmektedir. Kamu kesimi gelirlerini arttırmaya yönelik reformlar vergi yükünde adaletsizlik gibi çarpıklıkları azaltmaya odaklanmalıyken harcama reformları öncelikle harcamaların verimliliğini arttırmaya yönelik olmalıdır. Söz konusu politikalar sadece mali alanın oluşturulmasını sağlamaz, aynı zamanda orta ve uzun vadeli ekonomik büyümeye doğrudan katkıda bulunur. Bu açıdan mali alanın genişletilmesinde ülkelerin, tarafsız mali reformlara öncelik vermesi gerekmektedir (Çaşkurlu, 2011:20-27).

$\mathrm{Bu}$ noktada, maliye politikalarının uygulanmasının hem bir nedeni hem de sonucu olan mali alanın nasıl ölçüldüğü konusu da önem taşımaktadır. Mali alanın mali sürdürülebilirlik, mali disiplin ve mali yeterlilik gibi kavramlarla olan ilişkisi, ölçüm yönteminin de yine bu kavramlarla doğrudan ilişkili olması sonucunu doğurmaktadır. Dolayısıyla daha kapsayıcı bir kavram olan mali sürdürülebilirlik üzerinden mali alanı ölçme eğilimi bulunmaktadır. 
Mali alan ile mali sürdürülebilirlik arasındaki ilişkiye yönelik analizlerde, ilave bir kamu kesimi harcamasının bütçe dengesi üzerinde oluşturacağı etki incelenmektedir. Bu analizler; gelecekte ortaya çıkacak koşullar bugüne indirgenerek tahmin edilmesi yoluyla yapılmaktadır. $\mathrm{Bu}$ amaçla kullanılan yöntemlerin başında, zamanlar arası bütçe kısıtı yöntemi ve borçlanma limiti yaklaşımları gelmektedir. Zamanlar arası bütçe kısıtı yönteminden hareket eden analizlerde kamu borçlanma gereksiniminin GSYİH'ye oranının sabit kalması için verilmesi gereken faiz dışı bütçe fazlası göstergesinin GSYİH'ye oranı hesaplanmaktadır (Berke, 2009: 32). Yöntemde öncelikle; ne kadar faiz dışı fazla verilmesi gerektiği hesaplanmaktadır. Daha sonra ise mevcut faiz dışı fazla ile hesaplanan faiz dışı fazla karşılaş̧ırılmakta ve aralarındaki pozitif fark mali alan olarak nitelendirilmektedir. Borçlanma limiti yönteminden hareketle mali alanın ölçümünde ise mali alan ülkelerin gerçek borç seviyesi ile onların ekonomisinin tarihsel perspektifinin ortaya koyduğu potansiyel borç limiti arasındaki farktan yola çıkılarak tespit edilmektedir. Bu yöntemde, mevcut borç stoku ile borç limiti arasındaki fark mali alan olarak nitelendirilmektedir (Ulusoy vd. 2013:230).

Diğer taraftan uygulanacak maliye politikaları ile mali alan arasındaki ilişkinin yapısı ülkelerin gelişmişlik seviyelerine göre değişiklik göstermektedir. Ülkelerin makroekonomik politika hedeflerinin orta ve uzun vadede mali sürdürülebilirliğine olumsuz etkide bulunmayacak bir finansal kaynak yaratma kapasitesi olarak tanımlanan mali alan, tanımı gereği de her ülkede farkl11ık göstermektedir.

Ülkelerin demografik ve coğrafi yapısı, gelir toplayabilme ve harcama yapabilme gücü ile bileşenlerindeki farklılıklar ve başlıca bu faktörlerden kaynaklanan makroekonomik hedeflerdeki farklılıklar, mali alanın her ülkede benzerlik göstermemesine neden olan etkenler olarak belirtilebilir.

Schick'e göre, (2008) mali alanın oluşturulmasında genel olarak tüm ülkelerden orta ve uzun vadeli mali sürdürülebilirlikleriyle tutarlı maliye politikaları reformları yapması beklenmektedir. Gelir seviyesi düşük olan ülkelerde, kalkınmayı ve ekonomik büyümeyi teşvik etmek ve kamu kesimi gelirlerini arttırmak amaciyla ilave harcama yapma firsatını değerlendirmesi beklenmektedir. Orta gelirli veya gelişmekte olan ülkeler için kamu kesiminin gelecekteki mali pozisyonunu riske atmaksızın hızlı kalkınmayı teşvik etmesi beklenmektedir. Gelir seviyesi yüksek olan gelişmiş ülkelerden ise, orta ve uzun vadeli bütçe kararlarıla tahsis edebileceği finansman kaynaklarını değerlendirmesi beklenmektedir. $\mathrm{Bu}$ açıklamalardan hareketle mali alan kavramının farklı gelişme aşamalarındaki ülkeler için farklı anlamları olduğu sonucuna varılmaktadır. Düşük gelirli ülkeler açısından önemli olan husus, vergi tabanındaki yetersizlikler, yapısal mali dengesizlikler ve beşerî ile fiziki sermaye yatırımlarını yapabilmek için kaynakların nasıl yaratılacağıdır. Orta gelirli ülkeler açısından, vergi gelirlerinin GSYIH içindeki oranı, altyapı ve diğer yatırım harcamalarına bağlı olarak mali alan yaratma fırsatı bulunmaktadır. Gelişmiş ülkeler açısından ise ekonomik büyüme, gelir politikaları ve tasarruflar yoluyla yaratabileceği mali alanı nasıl tahsis edeceği sorusu önem kazanmaktadır. Diğer ülke gruplarından farklı olarak potansiyel büyüme sınırlarına yaklaşmış olan gelişmiş ülkelerin açısından, büyümeyi teşvik edecek bütçe politikaları ile gelecekteki mali alanı genişletebilme firsatları sınırlı olmaktadır.

\section{TÜRKİYE'DE MALİ ALAN VE KULLANIMINA İLIŞKİN DEĞERLENDIRME}

Türkiye'de mali alan oluşturma konusunda Atabey Ertürk (2013), Çaşkurlu (2011) ve Kaya (2010) tarafından yapılan çalışmalar bulunmakla birlikte Maliye Bakanlığının 2016 yılında yayımladığı Yıllık Ekonomik Rapor 'da Türkiye'nin mali alan oluşturma konusunda nispeten 
daha sade, kapsayıcı ve güncel göstergelere yer verilmiştir. $\mathrm{Bu}$ nedenle çalışmanın bu bölümünde ilgili raporun sunduğu bilgiler ışığında değerlendirilmeler yapılmaya çalışılacaktır.

Raporda, mali alan oluşturmaya yönelik göstergeler, faiz dışı fazla, faiz giderlerinin bütçedeki ve GSYIHH'deki payı ve faiz giderlerinin vergi gelirlerine oranı olarak belirlenmiştir. Söz konusu göstergelerle yapılan değerlendirmede Güçlü Ekonomiye Geçiş Programı'nın uygulanmaya başlanmasıyla, 2002 yılından itibaren faiz giderlerinin hem bütçe giderleri içindeki payının hem de GSYİH içindeki payının önemli ölçüde azaldığ 1 vurgulanmıştır. Buna göre 2002 yılında \%43,2 olan faiz giderlerinin bütçe içindeki payı 2014 yılında \%11,1'e, faiz giderlerinin GSYİH içindeki payının da aynı dönemde $\% 14,8$ 'den $\% 2,9$ seviyesine indiği; diğer taraftan 2002 yılında \%85,7 olan faiz giderlerinin vergi gelirlerine oranının 2014 yılında \%14,2'ye düştüğü ifade edilmiştir.

Raporda, faiz giderlerinin bütçe içindeki payının azalmasıyla sağlanan mali alanın eğitim, sağlık ve altyapı gibi alanlar için kullanıldığı ifade edilmiş olup Şekil 2'de gösterilmiştir. Ek olarak raporda, 2014-2018 dönemini kapsayan 10. Kalkınma Planı kapsamında 2015 yılında "Kamu Harcamalarının Rasyonelleştirilmesi Programı Eylem Planı" yürürlüğe konulduğu belirtilmiştir. Program çerçevesinde, mevcut harcama programları gözden geçirilerek verimsiz harcamaların tasfiye edilmesi, bu yolla oluşturulacak mali alanın öncelikli harcama alanlarına tahsis edilmesi ve faiz hariç harcamaların belirli bir seviyede tutulması amaçlanmıştır. Söz konusu program kapsamında;

I. Büyüme için gereken altyapı yatırımlarını tespit etmek üzere büyümeye daha fazla katkı sağlayacak öncelikli alanların belirlenmesine yönelik bir çalışma yürütülmesi,

II. Sektörel ve bölgesel yıllık yatırım tahsislerinin plan hedefleriyle uyumunun sağlanmas1,

III. Yatırım programındaki mevcut proje stoku önceliği ve etkinliği bakımından gözden geçirilerek stoktaki sorunlu projelerin tespit edilmesi ve gerekli tedbirler alınarak yatırım programının sürdürülebilirliğinin artırılması,

IV. Bütçe sisteminde yatırım-cari harcama sınıflandırması gözden geçirilerek söz konusu sınıflandırmaların kapsamları ile ilgili gerekli düzenlemelerin yapılması,

V. Yatırım projelerinin finansmanının (iç kaynak, dış kredi, hibe vb.) en uygun yöntemle sağlanmasına yönelik tedbirlerin alınması planlanmaktadır.

Tablo 2: Türkiye'de Mali Alan ve Kullanımı

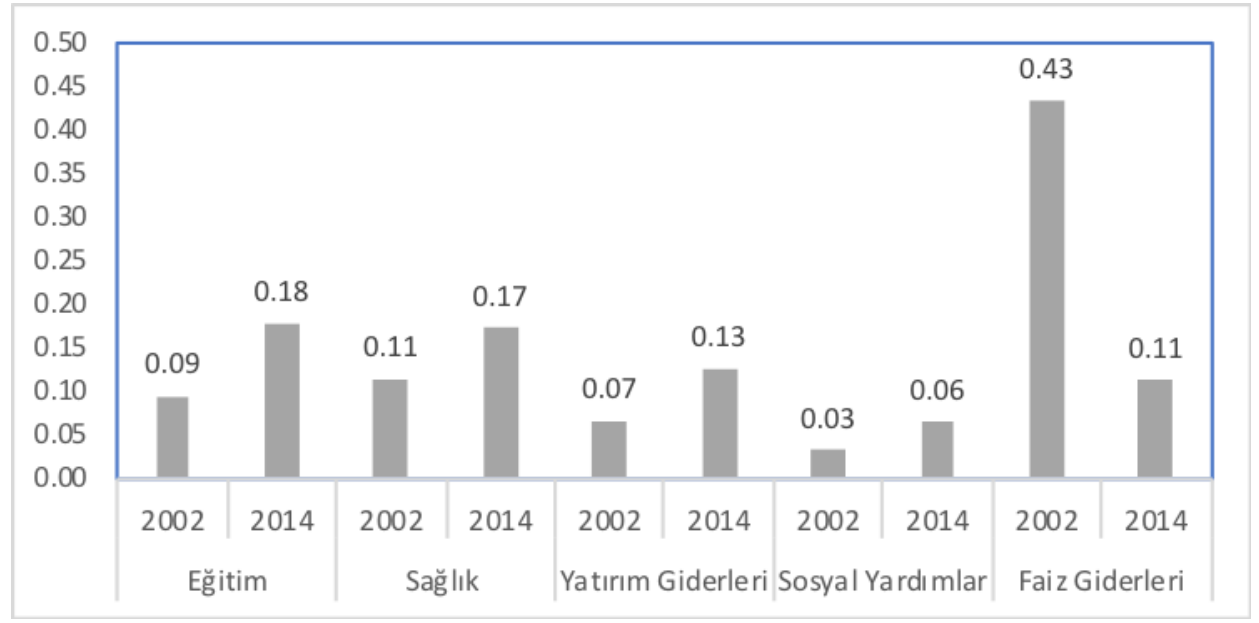

Kaynak: (Maliye Bakanlığı 2016 Y1llık Ekonomik Rapor,2015:53). 
Türkiye'de mali alan oluşturma performansına yönelik yapılan ulusal değerlendirmelere ek olarak, 2007 yılında IMF tarafindan yayımlanan raporda da birtakım analizlerde bulunulmuştur. Söz konusu raporun yayımlanma yılı her ne kadar eski olsa da yapılan analizlerin ve analizler sonucu sunulan önerilerin orta ve uzun vadeli olması nedeniyle güncelliğini koruduğu düşünülmektedir. Söz konusu analizde Türkiye'nin faiz dışı harcamalarını ve vergi yükünü azaltmayı içeren, ekonomik büyümeyi güçlendiren bir mali konsolidasyona ihtiyaç duyduğu ifade edilmektedir. Bir başka ifadeyle bütçe açığının ve kamu kesimi borç stokunun azaltılmas1, harcamaların azaltılması ve vergi oranlarının arttırılmas1 yoluyla gelirlerin arttırılması sonucunda mali alan oluşturmada önemli bir firsat kazanacağı önerilmektedir. Ek olarak, kamu kesimi harcamalarının ve vergilendirmenin seviyesi ve bileşimi, uzun vadede ekonomik büyümeye önemli bir katkı sağlayacağı ifade edilmektedir. Faiz dışı fazlaların borç dinamiklerinde ve makroekonomik istikrarın iyileşmesinde önemli bir katkısı olsa da kamu kesimi harcamalarının verimliliği konusunda yetersizliğin olduğu vurgusu yapılmıştır (IMF, 2007:25-26).

Şekil 3'de mali alan oluşturulmasında Türkiye'ye önerilen finansman kaynăg 1 gösterilmektedir.

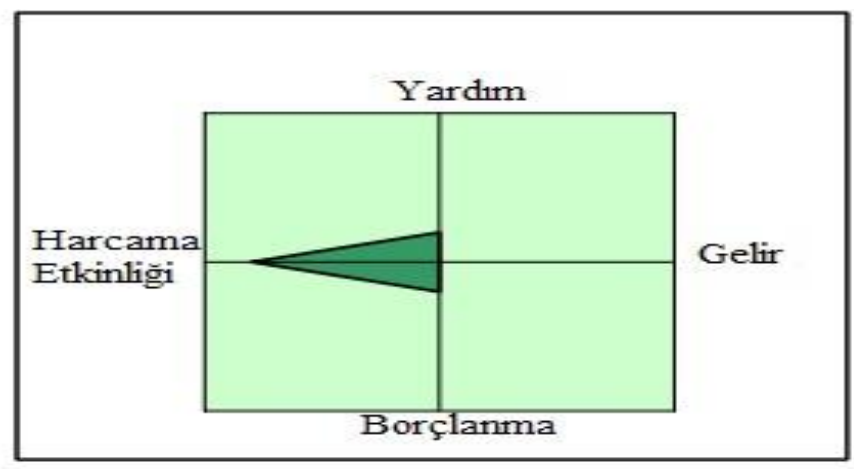

Şekil 3: Türkiye Mali Elmas1

Kaynak: (IMF, 2007:13).

Şekil 3'de sürdürülebilir bir büyüme için gerekli olan yatırımların yaratılması gereken mali alanın (Ukrayna ve Brezilya gibi benzer ülkelerle birlikte) Türkiye için hibe veya bağış, iç veya diş borçlanma ve kamu gelirlerini arttırma gibi finansman alternatiflerine yönelmek yerine piyasaya karşı mali güvenilirliğini olumsuz etkilemeyecek şekilde kamu harcamalarının bileşimine ve verimliliğine odaklanılması gerektiği görülmektedir. Bunun nedeni Türkiye'nin kamu kesimi gelirlerinin ve borç yükünün riskli seviyede olmasına ek olarak, piyasa erişiminin nispeten yüksek olmasıdır (IMF, 2007:13). Dolayısıyla piyasa dinamiklerinin nispeten gelişmiş olduğu Türkiye'de mali alan oluşturulmasında kamu kesimi harcamalarının etkinliği konusuna önem verilmesi gerekmektedir.

Maliye Bakanlığının raporuna göre (2016:42), IMF'nin çalışmasında belirtilen söz konusu eksiklerin giderilmesi amacıyla Türkiye hükümeti, 2015 yılında mevcut harcama programlarının gözden geçirilerek verimsiz harcamaların tasfiye edilmesi, bu yolla oluşturulacak mali alanın öncelikli harcama alanlarına tahsis edilmesi ve faiz hariç bütçe giderlerinin belirli bir seviyede tutulması amacıyla "Kamu Harcamalarının Rasyonelleştirilmesi Programı Eylem Planı"nı yürürlüğe koymuştur. $\mathrm{Bu}$ kapsamda ulaştırma, eğitim, tarım, sağlık, teknolojik araştırma, içme suyu, adalet hizmeti sektörleri ile bilgi ve iletişim teknolojilerinin geliştirilmesine yönelik altyapı yatırımlarına öncelik verileceği belirtilmektedir. 


\section{DEĞERLENDİRME VE SONUÇ}

Küreselleşme ile birlikte ülkelerin mali yapılarındaki değişiklikler diğer ülkeleri de etkilemeye başlamıştır. $\mathrm{Bu}$ etkinin en önemli sebeplerinden birisi finansal piyasaların hızla genişlemesi sonucu fon arz eden ile fon talep edenlerin herhangi birinde meydana gelecek finansal riskin diğerleri üzerinde önemli etkilere neden olmasıdır. Risklerin artması neticesinde ülkelerin mali istikrarı da bozulmakta; krizlere sebep olmaktadır. Bununla birlikte ülkelerin, ulusal alanda da birtakım sorumlulukları bulunmakta ve bu yükümlülükleri sürekli artış göstermektedir. Söz konusu görevler gelişmişlik seviyelerine göre farkl1lık arz etmekte; az gelişmiş ülkelerde temel sosyal, sağlık ve insani ihtiyaçlar, gelişmekte olan ülkelerde kalkınmanın hızlanması gerekliliği ve gelişmiş ülkelerde de kaynak tahsisinin değişen koşullara uyum sağlaması gibi konularda kendini göstermektedir. Dolayısıyla ulusal ve uluslararası etkenler nedeniyle mali sürdürülebilirliğin bozulma ihtimaline karşı, gelişmişlik seviyelerine bakılmaksızın ülkeler mali alan oluşturma çabasına girmişlerdir. Bu açıdan mali alan, birtakım risklerle karşı karşıya olan ülkelerin mali sürdürülebilirliğini garanti altına alan bir "bütçe odası" olarak ifade edilmektedir.

Birleşmiş Milletlerin 2000 yılında Binyıl Kalkınma Hedefleri ile gündeme getirdiği mali alanın oluşturulmasında "mali alan elması" olarak sembolize edilen dörtgeni oluşturan kamu gelirlerinin arttırılması, borçlanma, hibe ve yardım gibi doğrudan gelir yaratan seçenekler tercih edilebileceği gibi kamu kesimi harcamalarının etkinliğini arttırarak veya vergi idarelerinin denetim etkinliğinin iyileştirilmesiyle de dolaylı gelir kaynağı oluşturulabilmektedir. Bahsi geçen gelir kaynaklarının hangisinin seçilmesi konusunda başta IMF olmak üzere uluslararası finansal kuruluşlarının yönlendirmesiyle ve bu kaynakların kullanımı konusunda ${ }^{3}$ ülkeler önlemler almaktadır.

Diğer taraftan, Türkiye'de mali alan oluşturulmasına yönelik çabalar 2002 yılı Güçlü Ekonomiye geçiş Programı ile başlamış; özellikle faiz dışı fazla verilmesi gibi mali disiplinin göstergelerinin uygulanmasına önem verilmiştir. Maliye Bakanlığı'nın Yıllık Ekonomik Raporunda belirtildiği üzere, oluşturulan mali alan sonucu elde edilen finansman kaynakları eğitim, sosyal, sağlık ve yatırım harcamalarına aktarılmış; bu sayede beşerî ve fiziki sermaye göstergelerinde iyileşmelerin olduğu ifade edilmiştir. Ancak 2000'li y1llardan itibaren kısa vadeli spekülatif yabancı sermaye kaynaklarının önemli derecede artış göstermesi, mali alanın gelecekte daralmasına neden olmaktadır. Bununla birlikte, ihracatın ithalata bağımlı olması, enflasyonun artış göstermesi ve siyasi belirsizlik gibi etkenler Türkiye'nin mali alan oluşturmasına yönelik engellerini oluşturmaktadır.

Mali alan oluşturma hedefinde olan ülkelerin finansman sorununu çözmeye yönelik yöntemlere ek olarak, kamu harcamalarının miktarının yerine, verimliliğini arttırarak dolaylı gelir sağlamada olduğu gibi, nepotist tercihlerden uzak durarak, verimliliği yüksek olan işgücünü liyakat prensibiyle istihdam etme veya firsatını verme de önerilebilir. Bununla birlikte, kamu harcamalarının etkinliğini arttırmaya yönelik yapılacak sosyal devlet ilkesine aykırı uygulamalar yerine bürokrasi harcamalarında yapılacak mali regülasyonların hem düşük maliyetli hem de yüksek getirili bir mali alan oluşturma imkânı vereceği düşünülmektedir.

\footnotetext{
${ }^{3}$ IMF (2015), ülkelerin mali alan için mali reformlar yapması; bu kapsamda büyümeye yönelik ihtiyaç duyulan kaynakların oluşturulması ve harcanması konusunda özellikle harcamaların rasyonalizasyonunu ve etkinliğin yükseltilmesini önermektedir.
} 


\section{KAYNAKÇA}

Aşan, S. (2014). Özelleştirme ve mali alan ilişkisi. Yayımlanmamış yüksek lisans tezi, Çanakkale On Sekiz Mart Üniversitesi, TR

Atabey, S. E. (2013). Genç işsizliğine çözümde alternatif bir politika önerisi: mali alan uygulaması. Gençlik Araştırmaları Dergisi, 1(1), 171-187.

Berke, B. (2009). Avrupa parasal birliğinde kamu borç stoku ve enflasyon ilişkisi: panel veri analizi. Ekonometri ve Istatistik, 9, .30-55.

Çaşkurlu, E. (2011). Bağımsız maliye politikası uygulama olanağının kısıtlanması: mali alan daralması ve etkileri. Ekonomik Yaklaşım, 22(79), 21-44.

DPT. (2010). Binyıl kalkınma hedefleri raporu-Türkiye 2010. T.C. Başbakanlık Devlet Planlama Teşkilâtı Müsteşarlı̆̆ı: Birleşmiş Milletler Mukim Koordinatörlüğü.

Heller, P.S. (2005). Understanding fiscal space. (Report no:5/4). Washington, DC: IMF Discussion Paper.

Heller, P.S. (2006). The prospects of creating 'fiscal space' for the health sector. Health Policy and Planning, 21(2), 75-79.

IMF (2007). Fiscal policy for growth and development further analysis and lessons from country case studies. Development Committee Meeting,Washington, DC: IMF

IMF (2015). Fiscal policy and long-term growth. IMF Policy Paper Staff Report.

Kaya, F. (2010). Türk kamu mali yönetiminde örtük mali kurallar ve ülke tecrübelerinin değerlendirilmesi, C.C. Aktan, A. Kesik ve F. Kaya (der.). Mali Kurallar maliye politikasında yeni bir eğilim: vergi, harcama, borçlanma vs. üzerine kurallar ve sınırlamalar içinde. (Rapor no:2010/408), Ankara: Maliye Bakanlığı SGB Yayın, 380-405.

Linde, G. (2011). Fiscal space and development strategies. presented at the African fiscal forum, 9-10 November, Cape Town, South Africa. online at: http://www.treasury.gov.za/publications/other/AfricanFiscalForum/2011/english\%20version/Session3/3a/Notes\%20\%20World\%20bank\%20-\%20Gert\%20vd\%20Linde.pdf], Retrieved on June 29, 2017.

Maliye Bakanlığı (2016). Yıllık ekonomik rapor: 2015. Ankara: Maliye Bakanlığı.

Mendoza, E.G. ve Oviedo, P.M. (2009). Public debt, fiscal solvency and macroeconomic uncertainty in Latin America: the cases of Brazil, Colombia, Costa Rica and Mexico. Economía Mexicana Nueva Época, 18(2), 133-173.

Perotti, R. (2007). Fiscal policy in developing countries: A framework and some questions. Policy Research Working Paper (Report no:4365), Washington, DC:World Bank.

Roy, R,, Heuty, A \& Letouze, E. (2007). Fiscal Space for what? analytical issues from a human development perspective. Paper for the G-20 Workshop on Fiscal Policy. UNDP.

Schick, A. (2008). Budgeting for fiscal space. Asian OECD Senior Budget Officials Meeting, Thailand: Bangkok, [Available online at: https://www.oecd.org/gov/budgeting/39944230.pdf], Retrieved on October 14, 2017.

Ulusoy A., Akdemir T. ve Karakurt, B. (2013). Küresel kriz ve AB'nin kriz karşıtı maliye politikalarının etkinliği: mali alan açısından bir değerlendirme. 28. Türkiye Maliye Sempozyumu Küresel Kriz ve Maliye Politikaları Tebliğler Kitabı, 218-270.

UNCTAD (2014). Trade and development report 2014. Global Governance and Policy Space for Development, UN: New York and Geneva.

UNDP (2016). Insani gelişme raporu, özet: herkes için insani gelişme. UNDP, [Available online at: http://www.tr.undp.org/content/turkey/tr/home/library/human_development/human-development-report-20161.html], Retrieved on October 23, 2017.

Ünsal, E.M. (2009), Makro İktisat. Ankara: İmaj Yayıncılık.

Ünsal, H. ve Durucan, A. (2013). Kriz ortamında büyümenin sağlanmasına ilişsin yeni bir politika önerisi: mali alan uygulamaları ve değerlendirilmesi. 28. Türkiye Maliye Sempozyumu Küresel Kriz ve Maliye Politikaları Tebliğler Kitab1, 27-45.

World Bank (2006). Fiscal policy for growth and development: an interim report. WB Background Paper. (Report no: DC2006-0003).Washington:World Bank and International Monetary Fund.

World Bank (2009). World development indicators 2004. Washington, DC: World Bank. 